\title{
Penerapan Model Pembelajaran Contextual Teaching and Learning (CTL) dalam Meningkatkan Hasil Belajar
}

\author{
Irfan Taufik \\ Prodi Pendidikan Agama Islam, FTIK, IAIN Palopo \\ Email: Topiktfk78@gmail.com
}

\begin{abstract}
This research discusses the application of the Contextual Teaching and Learning (CTL) learning model in improving student learning outcomes, the purpose of the research in this paper is how to use the Contextual Learning learning model and Learning (CTL) can improve student learning outcomes. The type of research used in this study is classroom action research (CAR). The research subjects were students of class XI Administration 3 Vocational High School (SMK) Negeri 1 Palopo 2018/2019 academic year consisting of 7 male students and 18 female students. The data in this study were obtained from the results of observations of student activities (observation sheets) and final cycle test instruments. Furthermore, the data of this study were analyzed with qualitative descriptive. The learning model of Contextual Teaching and Learning (CTL) in the subjects can improve student learning outcomes. This can be seen from students who enthusiastically receive learning material and students are not ashamed to practice the material directly received, the results showed that during the final test Cycle I student learning outcomes amounted to $73.52 \%$, then in cycle II Discover the results of learning student learning material at $81.48 \%$ or around $7.91 \%$ in the realm of cognitive, affective, and psychomotor aspects.
\end{abstract}

Keywords: Contextual Teaching and Learning (CTL) Learning Model, Learning Outcomes of Islamic Education.

\begin{abstract}
Abstrak
Penelitian ini membahas tentang penerapan model pembelajaran Contextual Teaching and Learning (CTL) dalam meningkatkan hasil belajar siswa pada mata pelajaran Pendidikan Agama Islam tujuan penelitian ini adalah bagaimana penerapan model pembelajaran Contextual Teaching and Learning (CTL) dapat meningkatkan hasil belajar siswa pada mata pelajaran Pendidikan Agama Islam. Jenis penelitian yang digunakan dalam penelitian ini adalah penelitian tindakan kelas (PTK). Subjek penelitian adalah siswa kelas XI Adminitrasi 3 Sekolah Menengah Kejuruan (SMK) Negeri 1 Palopo tahun ajaran 2018/2019 yang terdiri dari 7 siswa laki-laki dan 18 siswi perempuan. Data dalam penelitian ini diperoleh dari hasil pengamatan aktivitas siswa (lembar observasi) dan instrument tes akhir siklus. Selanjutnya, data penelitian ini dianalisis dengan deskriptif kualitatif. Hasil dari penelitian menunjukan bahwa: penerapan model pembelajaran Contextual Teaching and Learning (CTL) dapat meningkatkan hasil belajar siswa. Hal tersebut dapat dilihat dari antusias siswa dalam menerima materi pembelajaran dan
\end{abstract}


siswa tidak malu mempraktikan secara langsung materi yang diterima, Hasil penelitian menunjukkan pada saat dilakukan tes akhir Siklus I hasil materi belajar siswa sebesar 73.52\%, selanjutnya pada siklus II terdapat peningkatan hasil materi belajar siwa sebesar $81.48 \%$ atau sekitar 7,91\% pada ranah aspek kognitif, afektif, dan psikomotorik

Kata Kunci: Model Pembelajaran, Contextual Teaching and Learning (CTL),.Hasil Belajar, Pendidikan Agama Islam.

\section{Pendahuluan}

Peranan model pengajaran merupakan hal yang sangat penting dalam proses belajar mengajar karena model dapat dijadikan sebagai faktor penentu dalam keberhasilan mencapai tujuan yang ingin dicapai dalam proses belajar mengajar di sekolah. Oleh karena itu, guru sebagai informan dalam proses belajar mengajar, hendaknya menguasai beberapa model mengajar yang sesuai dengan pokok pembahasan yang akan disajikan karena dengan mengguakan model yang sesuai akan menghasilkan lancarnya proses belajar mengajar dan secara otomatis prestasi belajar peserta didik akan meningkat.

Pembelajaran kontekstual atau Contextual Teaching and Learning (CTL) merupakan salah satu model pembelajaran yang dianggap mampu mengatasi keterkaitan materi Pendidikan Agama Islam dengan kehidupan siswa. Riset terdahulu tentang Contextual Teaching and Learning (CTL) menunjukan fokus dan variasi yang beragam. Pembelajaran Contextual Teaching and Learning (CTL) dapat mengurangi kesenjangan antara pembelajaran Pendidikan Agama Islam disekolah dengan kehidupan siswa dan membantu siswa menemukan makna dalam materi pembelajaran ${ }^{1}$, mengasosiasikan materi pembelajaran dengan dunia siswa ${ }^{2}$ dan keterlibatan penuh siswa untuk menghubungkan materi ${ }^{3}$.

Penelitian ini beragumen bahwa penerapan Contextual Teaching and Learning (CTL) dapat meningkatkan hasil belajar siswa pada tiga ranah pendidikan yakni kognitif, afektif, dan psikomotorik. Berbeda dengan model pembelajaran lain yang mengutamakan aspek kemampuan kognitif seperti metode diskusi, dan projek. Pembelajaran Contextual Teaching and Learning (CTL) ini mengajak siswa aktif dan membantu mengaitkan pelajaran akademis dengan konteks kehidupan siswa. Studi ini berargumen bahwa Contextual Teaching and Learning (CTL) tidak hanya dapat meningkatkan hasil belajar

${ }^{1}$ Elaine B Jhonson, Contextual Teaching and Learning: Menjadikan Kegiatan Belajar Mengajar Mengasyikan Dan Bermakna (Bandung: Khaifa Learning, 2014).

2 Masnur Muslich, KTSP Pembelajaran Berbasis Kompetensi Dan Kontekstual (Jakarta: Bumi Aksara, 2009).

3 Wina Sanjaya, Pembelajaran Dalam Implementasi Kurikulum Berbasis Kompetensi (Jakarta: Prenada Media Group, 2005). 
siswa pada ranah kognitif tetapi juga ranah aspek afektif dan psikomotorik secara bersamaan. Model penelitian ini menawarkan jalan untuk menuju keunggulan akademis yang dapat di ikuti oleh semua siswa. Berdasarkan beberapa pendapat para ahli di atas, dapat disimpulkan bahwa pembelajaran Contextual Teaching and Learning (CTL) adalah suatu model pembelajaran yang membantu guru dan siswa dalam proses pembelajaran dan pengajaran yang mengasilkan dan bermakna. Konsep kerja sama antara guru dan siswa dalam mengaitkan dan menghubungkan materi pelajaran akademis dengan konteks kehidupan sehari-hari.

Menurut EB. Jhonson, terdapat beberapa alasan mengenai pentingnya model pembelajaran Contextual Teaching and Learning (CTL). Pertama, pembelajaran Contextual Teaching and Learning (CTL) sesuai dengan nurani manusia yang selalu haus akan makna. Kedua, Contextual Teaching and Learning (CTL) membantu otak manusia untuk menghubungkan informasi baru dengan pengetahuan baru serta merangsang struktur otak dalam rangka merespon lingkungan. Ketiga, Contextual Teaching and Learning (CTL) sesuai dengan cara kerja alam yaitu belajar secara kontekstual berarti belajar mengeluarkan potensi penuh dalam diri siswa secara alamiah ${ }^{4}$. Allah swt., berfirman di dalam QS. 38/27 yang terjemahnya: ...dan kami tidak menciptakan langit dan bumi dan apa yang ada diantara keduanya dengan sia$\operatorname{sia}^{5}$.

Ayat di atas mengandung makna bahwa Allah swt., tidak pernah menciptakan apa yang ada dilangit dan dibumi itu sia-sia. Hubungan Antara pendapat para ahli dengan ayat di atas adalah keterkaitan suatu makna tentang alam semesta dengan pembelajaran akademik, ketika siswa menghubungkan materi akademik dengan pengalaman mereka sendiri, mereka menemukan makna dan makna memberi mereka alasan untuk belajar, mengaitkan pembelajaran dengan kehidupan dengan menjadikan alam semesta sebagai objek pembelajaran yang bermakna.

Berdasarkan observasi peneliti membuat kesimpulan pelaksanaan pembelajaran disekolah menengah kejuruan (SMK) negeri 1 palopo adalah $65 \%$ menggunakan metode ceramah, 15\% menggunakan metode diskusi, dan 20\% menggunakan metode penugasan. Dari kesimpulan tersebut maka peneliti di sini beranggapan bahwa proses pembelajar di sekolah menengah kejuruan (SMK) negeri 1 palopo yang di terapkan guru ini adalah model pembelajaran konvensional, yaitu pembelajaran yang hanya menekankan

${ }^{4}$ Jhonson, Contextual Teaching and Learning: Menjadikan Kegiatan Belajar Mengajar Mengasyikan Dan Bermakna.

5 Kementerian Agama Republik Indonesia, Al-Qur'an Keluarga, Sa'adah (Jakarta: Halim Publishing \& Distributing, 2013). 
siswa pada ranah kognitif saja, sedangkan untuk ranah afektif dan psikomotorik kurang begitu di perhatikan.

Berdasarkan kenyataan yang terjadi dilapangan, maka peneliti berinisiatif untuk melakukan penelitian Classroom Action Research (CAR), dengan merapkan model pembelajaran Contextual Teaching and Learning (CTL) yang mengaitkan antaran pelajaran akademis dengan konteks kehidupan siswa.

\section{Metode Penelitian}

Penelitian ini adalah penelitian tindakan kelas yang kegiatan penelitian tindakan yang berbasis kelas yang membantu guru meningkatkan mutu pembelajaran secara sistematis refleksi yang dilaksanakan dalam siklus berulang6. Adapun alur penelitian ini mengacu pada model Kemmis dan Mc. Taggart yang terdiri atas kegiatan perencanaan, tindakan, observasi, dan refleksi ${ }^{7}$. Keempat (4) komponen tersebut dipandang dalam satu siklus. Penelitian ini dilaksanakan di sekolah Menengah Kejuruan (SMK) Negeri 1 Palopo. Tempat ini dipilih karena penulis sendiri pernah melakukan PPL dan mengajar di sekolah Menengah Kejuruan (SMK) Negeri 1 Palopo tersebut sehingga memudahkan penulis berinteraksi dengan pihak sekolah. Dalam penelitian ini yang menjadi subjek adalah siswa kelas XI Adminitrasi tiga (3) Sekolah Menengah Kejuruan (SMK) Negeri 1 Palopo yang berjumlah 25 orang siswa, yang terdiri dari 7 siswa laki-laki dan 18 siswa perempuan.

Sumber data dalam penelitian ini adalah guru dan siswa kelas XI Adminitrasi tiga (3) Sekolah Menengah Kejuruan (SMK) Negeri 1 Palopo. Data yang terkumpul dalam penelitian ini berupa: (1). Data hasil observasi, (2). Data hasil evaluasi, (3). Data hasil wawancara. Teknik analisis data yang digunakan dalam penelitian yang akan dilaksanankan adalah tekhnik deskriptif kualitatif dengan persentase. Apabila datanya sudah terkumpul maka diklasifikasikan menjadi dua kelompok, yaitu data kuantitatif yang berwujud angka yang dijumlahkan dan dibandingkan dengan jumlah yang diharapkan untuk memperoleh persentasenya. Serta data kualitatif yaitu data yang berwujud kata-kata yang ditafsirkan dengan kalimat ${ }^{8}$

${ }^{6}$ Dadang Yudhistira, Menulis Penelitian Tindakan Kelas: Asli Perlu Ilmiah Konsisten $(A P I K)$, n.d.

${ }^{7}$ Suharsimi Arikounto, Prosedur Penelitian Suatu Pendekatan Praktik (Jakarta: PT Rineka Cipta, 2010).

${ }^{8}$ Lexy J Moleong, Metodologi Penelitian Kualitatif (Bandung: Remaja Rosdakarya, 2002). 
Adapun langkah perhitungan adalah dengan cara menghitung presentase jawaban benar yang di capai setiap siswa yang di rumuskan sebagai berikut :

$$
N_{P}=\frac{N_{K}}{N_{T}} \times 100 \%
$$

Keterangan:

$$
\begin{aligned}
& N_{P}=\text { Nilai Presentase } \\
& N_{K}=\text { Nilai yang di Dapat } \\
& N_{T}=\text { Nilai Jika di Hitung Semua }{ }^{9}
\end{aligned}
$$

Observasi aktivitas guru dan siswa dilakukan bersama dengan pelaksanaan kegiatan pembelajaran. Pelaksanaan observasi dilakukan oleh

\begin{tabular}{|c|c|}
\hline Interval & Kategori \\
\hline Baik & $75 \%-100 \%$ \\
\hline Cukup & $50 \%-74 \%$ \\
\hline Kurang & $49 \%$ \\
\hline
\end{tabular}
peneliti dengan menggunakan observasi yang mengacu pada kegiatan pembelajaran melalui model pembelajaran langsung ${ }^{10}$. Adapun aktivitas guru dan siswa yang diamati meliputi kegiatan pendahuluan, kegiatan inti dan penutup ${ }^{11}$. Sedangkan kategori aktivitas guru dan siswa adalah :

Tabel 1. Teknik deskriptif kualitatif ${ }^{12}$

Adapun untuk mengetahui perubahan hasil tindakan, jenis data yang bersifat kuntitatif yang didapatkan dari hasil evaluasi dianalisis dan dirubah menjadi kualitatif dengan menggunakan rumus :

${ }^{9}$ Ahmad Mujib, "Penerapan Pembelajaran Kontekstual Dalam Upaya Meningkatkan Prestasi Belajar Pendidikan Agama Islam Pada Siswa Kelas V SDN Karangasem 01 Sayung Demak Tahun Pelajaran 2010/2011” (IAIN Walisongo, 2011).

${ }^{10}$ Nurdianah Hanifah Julia, "Kurikulum 2013," in Prosiding Seminar Nasional Pendidikan Dasar Membedah Anatomi Kurikulum 2013 Untuk Membangun Masa Depan Pendidikan Yang Lebih Baik (Bandung: Universitas Pendidikan Indonesia, 2014).

11 Sajidan, "Peningkatan Hasil Belajar Mata Elajaran Fiqih Materi Tentang Ibadah Haji Dengan Menggunakan Metode Demonstrasi Di Kelas V MI Muhammadiyah Nambangan Kecamatan Selogiri Kabupaten Wonogiri," Jurnal Pendidikan Dwija Utama Forum Komunikasi Pengembangan Profesi Pendidik Kota Surakarta, 2008.

12 Anas Sudijono, Pengantar Statistik Pendidikan (Jakarta: Raja Grafindo Persada, 2007). 
$\mathrm{P}=\frac{\text { Post rate }- \text { Base rate }}{\text { Base } \text { Rate }} \times 100 \%$

Keterangan:

$\mathrm{P} \quad=$ Presentase peningkatan.

Post Rate = Nilai rata-rata sesudah tindakan

Base Rate $=$ Nilai rata-rata sebelum tindakan ${ }^{13}$

\section{Hasil Penelitian}

Aktifitas siswa pada siklus I di pertemuan pertama dan pertemuan kedua, memperlihatkan adanya respon yang baik terhadap metode pembelajaran Contextual Teaching and Learning (CTL), namun terlihat dalam proses pembelajaran, siswa masih agak kaku dan malu - malu dalam berdiskusi, hal ini mungkin dikarenakan siswa belum terbiasa dengan metode Contextual Teaching and Learning (CTL) dalam proses pembelajaran sehingga perlu kerja keras dan kesabaran dalam membimbing siswa. Terlihat pada saat proses diskusi siswa masih sungkan bertanya terhadap materi yang disampaikan kelompok temannya, masih ragu dan malu menjawab pertanyaan yang diajukan temannya dikarenakan mereka takut salah atau ditertawakan oleh teman lainnya. Ini menjadi pekerjaan rumah (PR) besar bagi penulis untuk dapat menimbulkan kepercayaan diri siswa dalam melaksanakan diskusi pada pelaksanaan siklus II. Berdasarkan hasil observasi aktifitas guru oleh pengamat, terlihat aktifitas guru pada siklus satu sudah cukup baik, namun masih kurang maksimal dalam memberikan motivasi pada siswa, ini akan diperbaiki pada pelaksanaan siklus II. Pada aktifitas siswa diketahui siswa masih ragu dan malu menyampaikan pendapatnya terhadap materi pembelajaran yang dipelajari sehingga perlu diberikan motivasi dan penguatan sebelum proses pembelajaran agar pelaksanaan diskusi dapat berjalan maksimal. Kurang maksimalnya aktivitas siswa dalam proses pembelajaran menyebabkan hasil belajar mereka yang kurang maksimal seperti diperlihatkan dalam Tabel 1.

${ }^{13}$ Zainal Aqib and Et.al, Penelitian Tindakan Kelas Untuk Guru SD, SLB,Dan TK (Bandung: Yrama Widya, 2009). 
Tabel 2. Hasil Belajar PAI Siswa Kelas XI Adminitrasi III Siklus I

\begin{tabular}{|c|c|c|c|c|c|}
\hline \multirow[b]{2}{*}{ No } & \multirow[b]{2}{*}{ Nama } & \multirow[b]{2}{*}{ Nilai } & \multirow{2}{*}{$\begin{array}{c}\% \\
\text { Ketercapaian }\end{array}$} & \multicolumn{2}{|c|}{ Ketuntasan } \\
\hline & & & & Tuntas & $\begin{array}{l}\text { Tidak } \\
\text { Tuntas }\end{array}$ \\
\hline 1 & Tri Ema & 76 & $76 \%$ & $\sqrt{ }$ & \\
\hline 2 & Dewi Aryanti Arista & 76 & $76 \%$ & $\sqrt{ }$ & \\
\hline 3 & Amanda Sri Wahyuni & 75 & $75 \%$ & $\sqrt{ }$ & \\
\hline 4 & Chillva Putri Rahayu & 76 & $76 \%$ & $\sqrt{ }$ & \\
\hline 5 & Nur Aliyah & 76 & $76 \%$ & $\sqrt{ }$ & \\
\hline 6 & Putri Puspita Sari & 78 & $78 \%$ & $\sqrt{ }$ & \\
\hline 7 & Pepri Sanggola & 75 & $75 \%$ & $\sqrt{ }$ & \\
\hline 8 & Endyta Salfaria F.N & 70 & $70 \%$ & & $\sqrt{ }$ \\
\hline 9 & Nur Santi & 71 & $71 \%$ & & $\sqrt{ }$ \\
\hline 10 & Jumriani & 76 & $76 \%$ & $\sqrt{ }$ & \\
\hline 11 & Ika Wahyuni & 71 & $71 \%$ & & $\sqrt{ }$ \\
\hline 12 & Karmila & 68 & $68 \%$ & & $\sqrt{ }$ \\
\hline 13 & Dea Wulandari & 76 & $76 \%$ & $\sqrt{ }$ & \\
\hline 14 & Putri & 76 & $76 \%$ & $\sqrt{ }$ & \\
\hline 15 & Hanzah Angelia Azizah & 77 & $77 \%$ & $\sqrt{ }$ & \\
\hline 16 & Anggi Angraeni Rahayu & 79 & $79 \%$ & $\sqrt{ }$ & \\
\hline 17 & Delvi Rustam & 76 & $76 \%$ & $\sqrt{ }$ & \\
\hline 18 & Arief Budi Setiawan R. & 75 & $75 \%$ & $\sqrt{ }$ & \\
\hline 19 & Muhammad Halid & 71 & $71 \%$ & & $\sqrt{ }$ \\
\hline 20 & Dicky & 68 & $68 \%$ & & $\sqrt{ }$ \\
\hline 21 & Aprian & 68 & $68 \%$ & & $\sqrt{ }$ \\
\hline 22 & Kahlil Gibran & 73 & $73 \%$ & & $\sqrt{ }$ \\
\hline 23 & Adam Pratama & 68 & $68 \%$ & & $\sqrt{ }$ \\
\hline 24 & Gilang Ramadhan & 68 & $68 \%$ & & $\sqrt{ }$ \\
\hline 25 & Musfira Yusuf & 75 & $75 \%$ & $\sqrt{ }$ & \\
\hline & Jumlah & 1838 & 18.38 & 15 & 10 \\
\hline & Nilai Rata-Rata & 73.52 & $73,52 \%$ & $60 \%$ & $40 \%$ \\
\hline
\end{tabular}

Berdasarkan hasil observasi yang dilakukan oleh guru kelas XII Adminitrasi 3 di Sekolah Menengah Kejuruan (SMK) Negeri 1 Palopo, bahwa peneliti telah berusaha semaksimal mungkin meningkatkan kinerjanya dalam melaksanakan proses pembelajaran menggunakan metode Contextual Teaching and Learning (CTL). Dalam meningkatkan hasil belajar dan penguatan kepada siswa serta dalam pengelolaan waktu lebih baik dari sebelumnya, karena sudah mempunyai pengalaman pada siklus sebelumnya. 
aktivitas siswa meningkat dari sebelumnya siswa sangat bersemangat mengikuti kegiatan pembelajaran dan tidak merasa bosan. Saling bertukar pendapat antar anggota kelompok, siswa terlihat lebih aktif dan lebih akrab dari sebelumnya, serta terlihat lebih kompak sehingga siswa merasa senang selama proses pembelajaran. Siswa terlihat lebih siap mengikuti pembelajaran karena sudah punya pengalaman disiklus sebelumnya. Peran guru sangat berpengaruh terhadap peningkatan hasil belajar siswa dalam kelompoknya. Terlihat sebagian besar siswa tidak ragu-ragu dan malu lagi dalam menyampaikan pendapatnya, walaupun pendapat yang mereka sampaikan mengundang sedikit tawa teman - temannya namun pendapat dan pertanyaan yang mereka ungkapkan cukup baik dan sesuai dengan materi pembelajaran.

Hasil observasi aktifitas guru dan siswa serta hasil tes akhir siswa pada tindakan siklus II memberikan hasil yang baik dalam pelaksanaan penelitian tindakan, walaupun masih ada sebagian siswa yang tidak tuntas, namun nilai persentase ketuntasan kelas menunjukan bahwa siswa telah tuntas secara klasikal atau dengan kata lain penggunaan metode diskusi pada pelaksanaan tindakan siklus II dapat meningkatkan hasil belajar siswa. Untuk lebih jelasnya hasil belajar siswa kelas XII Adminitrasi III di Sekolah Menengah Kejuruan (SMK) Negeri 1 Palopo diperlihatkan dalam Tabel 2.

Tabel. 3 Hasil Belajar PAI Siswa Klelas XII Adminitrasi III Siklus II

\begin{tabular}{|c|l|c|c|c|c|}
\hline \multirow{2}{*}{ No } & \multicolumn{1}{|c|}{ Nama } & Nilai & \multirow{2}{*}{$\begin{array}{c}\text { Kotan } \\
\text { Ketercapaian }\end{array}$} & \multicolumn{2}{|c|}{ Ketuntasan } \\
\cline { 5 - 6 } & & & & Tuntas & $\begin{array}{c}\text { Tidak } \\
\text { Tuntas }\end{array}$ \\
\hline 1 & Tri Ema & 86 & $86 \%$ & $\sqrt{ }$ & \\
\hline 2 & Dewi Aryanti Arista & 84 & $84 \%$ & $\sqrt{ }$ & \\
\hline 3 & Amanda Sri Wahyuni & 81 & $81 \%$ & $\sqrt{ }$ & \\
\hline 4 & Chillva Putri Rahayu & 83 & $83 \%$ & $\sqrt{ }$ & \\
\hline 5 & Nur Aliyah & 81 & $81 \%$ & $\sqrt{ }$ & \\
\hline 6 & Putri Puspita Sari & 78 & $78 \%$ & $\sqrt{ }$ & \\
\hline 7 & Pepri Sanggola & 78 & $78 \%$ & $\sqrt{ }$ & \\
\hline 8 & Endyta Salfaria F.N & 85 & $85 \%$ & $\sqrt{ }$ & \\
\hline 9 & Nur Santi & 81 & $81 \%$ & $\sqrt{ }$ & \\
\hline 10 & Jumriani & 82 & $82 \%$ & $\sqrt{ }$ & \\
\hline
\end{tabular}




\begin{tabular}{|c|c|c|c|c|c|}
\hline \multirow[b]{2}{*}{ No } & \multirow[b]{2}{*}{ Nama } & \multirow[b]{2}{*}{ Nilai } & \multirow{2}{*}{$\begin{array}{c}\% \\
\text { Ketercapaian }\end{array}$} & \multicolumn{2}{|c|}{ Ketuntasan } \\
\hline & & & & Tuntas & $\begin{array}{c}\text { Tidak } \\
\text { Tuntas }\end{array}$ \\
\hline 11 & Ika Wahyuni & 81 & $81 \%$ & $\sqrt{ }$ & \\
\hline 12 & Karmila & 79 & $79 \%$ & $\sqrt{ }$ & \\
\hline 13 & Dea Wulandari & 81 & $81 \%$ & $\sqrt{ }$ & \\
\hline 14 & Putri & 81 & $81 \%$ & $\sqrt{ }$ & \\
\hline 15 & Hanzah Angelia Azizah & 81 & $81 \%$ & $\sqrt{ }$ & \\
\hline 16 & Anggi Angraeni Rahayu & 88 & $88 \%$ & $\sqrt{ }$ & \\
\hline 17 & Delvi Rustam & 85 & $85 \%$ & $\sqrt{ }$ & \\
\hline 18 & Arief Budi Setiawan R. & 83 & $83 \%$ & $\sqrt{ }$ & \\
\hline 19 & Muhammad Halid & 83 & $83 \%$ & $\sqrt{ }$ & \\
\hline 20 & Dicky & 81 & $81 \%$ & $\sqrt{ }$ & \\
\hline 21 & Aprian & 78 & $78 \%$ & $\sqrt{ }$ & \\
\hline 22 & Kahlil Gibran & 79 & $79 \%$ & $\sqrt{ }$ & \\
\hline 23 & Adam Pratama & 79 & $79 \%$ & $\sqrt{ }$ & \\
\hline 24 & Gilang Ramadhan & 80 & $80 \%$ & $\sqrt{ }$ & \\
\hline 25 & Musfira Yusuf & 79 & $79 \%$ & $\sqrt{ }$ & \\
\hline & Jumlah & 2037 & 20.37 & 25 & \\
\hline & Nilai Rata-Rata & 81.48 & $81.48 \%$ & $100 \%$ & \\
\hline
\end{tabular}

\section{Pembahasan}

Pelaksanaan penelitian tindakan kelas dengan menggunakan metode diskusi diharapkan dapat meningkatkan hasil belajar siswa kelas XII Adminitrasi III Sekolah Menengah Kejuruan (SMK) Negeri 1 Palopo pada mata pelajaran PAI. Pada pelaksanaan tindakan siklus I terlihat aktifitas guru sudah baik hanya masih terdapat beberapa kekurangan seperti pengelolaan waktu yang kurang ini diakibatkan peneliti yang bertindak sebagai guru terlalu serius mengamati siswa dalam melaksanakan diskusi. Selain itu dari hasil observasi aktifitas guru pada siklus I diketahui bahwa dalam meningkatkan hasil belajar siswa masih kurang maksimal, ini berimbas pada aktifitas siswa yang terlihat kurang maksimal dalam proses pembelajaran. Aktifitas siswa pada pelaksanaan tindakan siklus I, menunjukan sikap antusias yang baik, karena terlihat siswa begitu serius dalam memperhatikan penjelasan guru yang memaparkan materi pembelajaran secara garis besar, namun dalam pelaksanaan diskusi siswa masih kurang maksimal seperti siswa terlihat masih sungkan dalam berbicara, baik menyampaikan pendapatnya, menanyakan hal - hal yang kurang jelas serta menyampaikan jawabannya terhadap pertanyaan yang di tanyakan oleh temannya yang berasal dari kelompok lain, hal ini mengakibatkan sebagian besar siswa tidak terlalu 
memahami materi yang sedang di pelajari sehingga mengakibatkan hasil belajar yang mereka dapatkan kurang maksimal. Dari hasil tes akhir siklus I, diketahui bahwa jumlah siswa yang tuntas pada pelaksanaan tindakan siklus satu ada 15 siswa, dan yang tidak tuntas ada 10 siswa ketika dihitung persentase ketuntasan belajar klasikal, didapatkan nilai persentase ketuntasan belajar klasikal siswa kelas XII Adminitrasi III Sekolah Menengah Kejuruan (SMK) Negeri 1 Palopo pada pelaksanaan tindakan siklus I 60\%, ini menunjukan bahwa siswa belum tuntas secara klasikal, walaupun demikian, penerapan metode Contextual Teaching and Learning (CTL) pada siklus I telah memperlihatkan adanya peningkatan hasil belajar siswa dari proses pembelajaran sebelumnya memperoleh persentase ketuntasan belajar klasikal sebesar adalah $60 \%$ namun penelitian belum dapat dikatakan berhasil karena persentase ketuntasan belajar klasikal belum mencapai 75\%.

Pada pelaksanaan tindakan siklus II, terlihat adanya peningkatan aktifitas guru, seperti pengelolaan waktu lebih baik, serta pemberian motivasi dan penguatan terhadap siswa pun terlihat lebih maksimal hal ini karena telah ada pengalaman sebelumnya pada siklus I. Dalam menyampaikan motivasinya guru menyampaikan bahwa kita diruangan ini masih dalam proses pembelajaran, sehingga jika ada kekurangan dan kesalahan merupakan hal yang wajar sehingga siswa tidak perlu merasa malu ataupun ragu untuk mengeluarkan pendapatnya. Sebab jika mereka selalu ragu dan takut salah dalam proses pembelajaran maka itu akan merugikan diri sendiri. Dengan adanya motivasi dan penguatan yang maksimal dari guru pada siklus dua, mampu membangkitkan kepercayaan diri siswa, terlihat dalam proses diskusi sebagian besar siswa terlihat lebih aktif, siswa tidak ragu lagi menanyakan hal - hal yang belum dipahaminya dari materi yang dipelajari, siswa lebih percaya diri ketika menjawab pertanyaan temannya. Pada pelaksanaan tindakan siklus dua, hasil belajar siswa mengalami peningkatan yang baik dari siklus sebelumnya, jika pada siklus I hanya ada 15 siswa yang tuntas maka pada pelaksanaan tindakan siklus II ada 25 orang siswa yang tuntas mengikuti pembelajaran dari 25 orang siswa kelas XII Adminitrasi III Sekolah Menengah Kejuruan (SMK) Negeri 1 Palopo. Persentase ketuntasan belajar klasikal yang didapatkan pada siklus II sebesar 99\%, dengan nilai presentase ini dapat dikatakan bahwa siswa kelas XII Adminitrasi III Sekolah Menengah Kejuruan (SMK) Negeri 1 Palopo telah tuntas secara klasikal dalam pembelajaran PAI.

\section{Penutup}

Penerapan metode Contextual Teaching and Learning (CTL) dapat meningkatkan Hasil belajar siswa kelas XII Adminitrasi III Sekolah Menengah Kejuruan (SMK) Negeri 1 Palopo pada mata pelajaran PAI dengan persentase ketuntasan belajar klasikal sebesar 75\%. Dalam penerapan metode Contextual 
Teaching and Learning (CTL), pemberian motivasi pada siswa harus maksimal agar dapat membangkitkan kepercayaan diri siswa dalam berdiskusi dengan temannya.

Guru diharapkan mampu mengembangkan kegiatan pembelajaran untuk memberikan pengalaman belajar yang melibatkan proses mental dan fisik melalui interaksi antar siswa, siswa dengan guru, lingkungan dan sumber belajar lainya dalam rangka pencapaian kompetensi dasar. Pengalaman belajar dapat terwujud melalui penggunaan pendekatan pembelajaran yang bervariasi dan berpusat pada siswa

\section{Daftar Pustaka}

Aqib, Zainal, and Et.al. Penelitian Tindakan Kelas Untuk Guru SD, SLB,Dan TK. Bandung: Yrama Widya, 2009.

Arikounto, Suharsimi. Prosedur Penelitian Suatu Pendekatan Praktik. Jakarta: PT Rineka Cipta, 2010.

Indonesia, Kementerian Agama Republik. Al-Qur'an Keluarga. Sa'adah. Jakarta: Halim Publishing \& Distributing, 2013.

Jhonson, Elaine B. Contextual Teaching and Learning: Menjadikan Kegiatan Belajar Mengajar Mengasyikan Dan Bermakna. Bandung: Khaifa Learning, 2014.

Julia, Nurdianah Hanifah. "Kurikulum 2013.” In Prosiding Seminar Nasional Pendidikan Dasar Membedah Anatomi Kurikulum 2013 Untuk Membangun Masa Depan Pendidikan Yang Lebih Baik. Bandung: Universitas Pendidikan Indonesia, 2014.

Moleong, Lexy J. Metodologi Penelitian Kualitatif. Bandung: Remaja Rosdakarya, 2002.

Mujib, Ahmad. "Penerapan Pembelajaran Kontekstual Dalam Upaya Meningkatkan Prestasi Belajar Pendidikan Agama Islam Pada Siswa Kelas V SDN Karangasem 01 Sayung Demak Tahun Pelajaran 2010/2011." IAIN Walisongo, 2011.

Muslich, Masnur. KTSP Pembelajaran Berbasis Kompetensi Dan Kontekstual. Jakarta: Bumi Aksara, 2009.

Sajidan. "Peningkatan Hasil Belajar Mata Elajaran Fiqih Materi Tentang Ibadah Haji Dengan Menggunakan Metode Demonstrasi Di Kelas V MI Muhammadiyah Nambangan Kecamatan Selogiri Kabupaten Wonogiri." Jurnal Pendidikan Dwija Utama Forum Komunikasi Pengembangan Profesi Pendidik Kota Surakarta, 2008.

Sanjaya, Wina. Pembelajaran Dalam Implementasi Kurikulum Berbasis Kompetensi. Jakarta: Prenada Media Group, 2005. 
Sudijono, Anas. Pengantar Statistik Pendidikan. Jakarta: Raja Grafindo Persada, 2007.

Yudhistira, Dadang. Menulis Penelitian Tindakan Kelas: Asli Perlu Ilmiah Konsisten (APIK), n.d. 